\title{
Hukukun Ekolojisi: Doğa ve Toplumla Uyumlu Bir Hukuk Sistemine Doğru
}

\author{
Fritjof Capra, Ugo Mattei, Çev. Ebru Kılıç, \\ İstanbul, Koç Üniversitesi Yayınları, 2017, 240 sayfa, \\ ISBN: 9786059389464
}

İnsanlar ve insanların kurdukları şirketlerin Dünyanın sınırlı kaynaklarını sınırsız bir iştahla ele geçirme ve biriktirme arzusunun ortaya çıkardığı çevre problemleri, sınırlar ve kuşaklar ötesi problemlere yol açtı. İnsanlığ 1 tehdit eder hale gelen küresel isınma, iklim değişikliği, ekolojik dengenin bozulması, su ve enerji kaynaklarının azalması gibi sorunlar doğal kaynakların tahrip edilmeden gelecek nesillere nasıl aktarılabileceği kaygılarını da beraberinde getirdi. Doğanın birbiriyle etkileşen, kendini yenileyen, sürdürülebilir ekosistemi insanoğlunun hırsına, hızına ve doğa üzerinde her türlü tasarrufta bulunabilme hakkı olduğu düşüncesine yenik düştü. Ekonominin ve ekonomik göstergelerin her şeyi belirlediği bir paradigma anlayışına geçildi. Daha fazla bu korkutucu duruma kayıtsız kalmak mümkün müdür? Dünyanın var olan kaynaklarının daha adil, verimli ve sürdürülebilir şekilde kullanılması her bir insanın hem hakkı hem de sorumluluğudur. Sorumluluk birkaç kişi, kurum ya da kuruluşa değil bütün insanlığa aittir.

Fizikçi ve sistem tasarımcısı Fritjof Kapra ve hukukçu Ugo Mattei'nin dünyanın gidişatına karşı "böyle gitmez" çıkışıyla kaleme aldıkları Hukukun Ekolojisi kitabında bugünlere nasıl gelindiği ve çıkış yolu tartışılmaktadır. İki yazar okuyucularını dünden bugüne batı merkezli bilim ve hukuk tarihinin sayfalarında dolaştırarak bugün yaşanılan krizin sorumlusunun kimler ve neler olduğunu ortaya koymaya çalışmaktadır. Çıkış yolu olarak ekonomik insandan (homo economius) ekolojik insana (homo ecologius) evrilen bir paradigma değişimini öneren yazarlar hukukun Dünya' yı korumak için önemli bir araca dönüştürülebileceği inancına sahiptir. 
Hukukun Ekolojisi adlı kitap, antik çağlardan modern zamanlara bilim ve hukukun tarihini biraraya getirerek birbirlerinden etkileşimlerini ortaya koymasıyla alanında bir ilk özelliği taşımaktadır. Bilim tarihi ve hukukla ilgilenlerin ilgisini çekecek pek çok bilgiyi barındıran eser kamu politikası oluşturmak isteyenler için bir rehber kitap olma özelliği taşımaktadır. Kitap, üç temel mevzu etrafinda ve girişle birlikte 10 bölümde; bilim ve hukuk ilişkisi, bilim ve hukuk anlayışından beslenen modernizmin yol açtığı problemler ve bilimde yaşanılan anlayış değişikliğiyle beraber hukuk anlayışının değiştirilmesi etrafında tartışmalarını sürdürmektedir.

Akışkan bir tarihsel süreç içerisinde bilim tarihindeki değişiklikleri ve gelişmeleri anlatan Capra ve Mattei, okuyucularını öncelikle antik çağa götürmekte ancak en çok da modernizmin geliştiği ve bilimsel devrimler çağı olarak adlandırılan 16. ve 17. yüzyılın gelişmelerinde tarihi bir yolculuk yaptırmaktadır. Kitapta; antik çağ'dan 16. ve 17. yüzyıla kadar batıdaki filozofların dünyayı bir kozmos, düzenli ve uyumlu bir yapı, mekanik bir sistemden ziyade canlı bir organizma olarak gören anlayışının yerini bilimsel devrimler çağında dünyayı bir makine olarak gören bakış açısının aldığ 1 gösterilmektedir. Descartes'in "Bir saatin işleyişiyle bir ağacın büyümesi aynı kurallara tabidir" görüşü bu mekanikçi kuramı en temel biçimde açıklamaktadır. Bu bakış açısının, 20. yüzyılın sonlarına dek modern dönemin baskın metaforu olmayı sürdürdüğü anlaşılmaktadır.

Modernitenin yol açtığ 1 problemlere değinilen kısımlarda yazarlar, bilimsel devrimin tetiklediği modernitenin akılcılık, bireycilik ve durmaksızın ilerleme inancı ve pratiklerine sahip olduğunu belirtmişlerdir. Modernist düşüncede bilimin amacının doğaya hâkim olmak ve onu kontrol altına almak için kullanılabilecek bilgilerin peşinden gitmektir. Modernitenin bu anlayış1 doğanın yeni efendisini insanoğlu olarak ilan etmiştir. 16. ve 17. yüzyıldan itibaren bilimin ve özel mülkiyet ile egemenliği temel hak olarak gören hukuk anlayışının desteklediği insanın doğa üzerindeki sahipliği ve hakimiyet fikri, üç yüz yıl içerisinde sermaye bolluğuna yol açarken müşterek alanların kitlığına yol açtı. Modernist dönemin başlangiciyla birlikte bilim sayesinde insanlar doğayı çözmüş özel mülkiyet ve egemenlik görüşüyle doğa bir meta haline dönüşmüş ve Dünya'nın, herkesin ortak malı olduğu görüşü yerini birbiriyle rekabet halindeki bireysel mal sahiplerinin tüm kaynakları kontrol ettiği, parçalanmış toprak sistemine bırakmıştı. Tüm değerler, kişilerin ve şirketlerin zenginliklerini ne kadar artırdıklarını belirten rakamlara indirgenerek gösterilmeye başlandi.

Capra ve Mattei, 20. yüzyılın başında 16. ve 17. yüzyıldan itibaren bilim dünyasında hâkim olan paradigmalarda büyük değişikliklere yol açan gelişmeler yaşandığını ve bu değişikliklerin fizik alanında yaşanılan gelişmelerle başladığını gözlemlemektedir. 20. yüzyılın başlangıcıyla kuantum 
ve görelilik kuramı fizik anlayışında devrime yol açtı. Fizik alanında yaşanan devrim biyoloji, psikoloji ve çevre bilimlerinde de görüldü. Artık, doğa parçalardan oluşan bir bütün yerine bizatihi yekpare bir bütün ve canlı bir varlık olarak kabul ediliyordu. Bu aynı zamanda antik çağdan bilimsel devrime kadar ki dönemin sahip olduğu hakikatti. Böylelikle dünyanın makine olarak görülmesi yerine ă̆ olarak anlaşılması yönünde bir paradigma değişimi yaşand. Bu gelişmelerden ve etkileşimlerden "sistem" düşüncesi" ya da "sistemci" düşünme diye bilinen yeni bir düşünme biçimi doğdu. 16. ve 17. yüzyıldaki parçaların bütünü oluşturduğu görüşü yerini Aristoteles'in "Bütün, parçaların toplamından daha büyüktür" düşüncesine bıraktı. Modernizmin "makine" metaforu "ağ" metaforuyla değişti. Bu metafora göre dünya bir ilişkiler ve ağlar bütününden ibaretti.

İki yazar, bilim dünyasındaki bu paradigma değişikliğinin maalesef hukuk sahasında henüz bir değişime yol açmadığını ve hukuk kuramında mekanikçi düşünce anlayışında değişim olmadığını endişelenerek anlatmaktadır. Mekanikçi hukuk sisteminin kapitalizme hizmet ettiğini iddia eden yazarlar bu durumun kaynakların belirli kişiler ve şirketlerin elinde toplanmasıyla sonuçlandığını ileri sürmektedir. Onlara göre mülkiyeti, kullanılmayan kaynakları işgal etme özgürlüğ̈̈ olarak gören mekanikçi bakış açısının hukuken hala desteklediği yeni küresel kapitalizm, dünyanın dört bir yanındaki yerel toplulukları tehdit etmekte ve yıkıcı olmaktadır. Bireyselleşme ve güçsüzleşmeyi ortaya koyan bu kasvetli tablo bir doğa kanununun değil hukuksal düzenlemelerin sonucuydu. Capra ve Mattei, insanlar ile doğa arasındaki ilişkinin mekanikçi bir yaklaşımla ele alınmasına dayalı mülkiyet hukukunun, hala en güçlü dışlama, bireyselleştirme ve rekabetçi birikim kurumu olarak varlığını olduğu gibi sürdürmesini kabullenememektedir.

Sosyal bir canlı olarak tanımlanan insanoğlu yalnızlaşmaya ve yabancılaşmaya ve daha çok kazanma hırsına kendi çitlerini çevreleyerek başladı. Bunun sonuçlarından birisi de bugün şehirlerde yaşayan insanların doğadan kopmuş ve en temel ihtiyaçlarını bile karşılamak için başkalarına muhtaç olduğu bir durumla karşılaşmış olmasıdır. Capra ve Mattei, toprakların insanlar ve doğayla ilişki kurulan bir yaşama alanından "geliştirmeye" elverişli, metalaştıılmış araziye dönüştürülmesinin, "benzin istasyonu" ve "alışveriş merkezleriyle" dolu, ölü ve tek kültürlü bir coğrafya ortaya çıkardığını söyleyerek kitapta bu karamsar tablodan çıkış için ne yapılması gerektiği sorusuna cevap bulmaya çalışmaktadır. Çözümleri ise geçmişe özlem duyarak değil geleceği düzgün tasarlayarak gerçekleşebilecek bir anlayış değişikliği içeriyor.

Hukukun değiştirilebilir, insanlar tarafindan insanlar için yazılan bir araç olduğunun ve hukukun doğanın ekolojisine uygun bir anlayışa dönüştürülmesi gerektiğinin unutulmaması gerekmektedir. Capra ve Mattei, bunun için artık 
bol miktarda bulunan sermayenin, belirli şahısların ve şirketlerin değil bütün toplumun doğayla uyumlu ve sosyal bir hayat yaşamasına hizmet eden müşterek varlıkların çoğalmasına hizmet edecek biçimde kullanılmasının gerektiğini ileri sürmektedirler. Belirli ellerde toplanılan sermayenin daha fazla AVM ve rezidanslara harcanmasının teşvik edilmesi yerine insanların ortak kullanımına hizmet edecek somut ve somut olmayan kültürel miraslara, müze ve dinlenme yerlerine, toplum taşım araçlarına harcanması müştereklerin çoğalabileceği bir dünyada yaşamaya hizmet edecektir. Capra ve Mattei'ye göre "Daha fazla" yerine "yeterince" ekonomisine geçmek ve zenginliği sadelikte aramak herkesin yeterince ihtiyaçlarını karşılayabilecek bir kaynak dağılımına izin verecektir. Müşterek varlıklar söz konusu olduğunda piyasa bir başarı ölçüsü olarak kullanılmayacaktır. Müşterek varlıkların çoğalması ahlaki olmakla birlikte, beraberinde ekonomik olarak da sürdürülebilir bir dünyada yaşamamızı sağlayacaktır.

Fizik kanunlarının bile değiştiği bir durumda insanların yaptıkları kanunların değişmeden kalması beklenilmemelidir. Kitap, hukuku mekanikçi bir görüşe yardım eden bir konumdan çıkararak tıpkı doğa gibi kendi kendini tamir edebilen, üretken ve müşterekleri koruyan bir konuma getiren bir sistemi kurmakla sorumlu olduğumuzu hatırlatmaktadır. Hukuk ancak böyle bir durumda kendi ekolojisini oluşturabilecek, kendi ihtiyaçlarımızı ve heveslerimizi gelecek kuşakların bedelini ağır bir biçimde ödemeyeceği şekilde karşılayabileceğiz. Hukukun bu yeni anlayışı; kamu politikalarının oluşturulmasında üretken, problemleri çözen, sürdürülebilir sistemlerin kurulması ve problemlerin çözülmesine yardımcı olabilecektir.

Kitabın belki de en büyük eksikliği bütün dünyayı sar(s)an modernist hukuk anlayışının nasıl doğanın kanunlarıyla uyumlu bir hukuk anlayışıyla yer değiştireceğine dair yeterince somut öneriler içermemesi ve okuyucular için fazlaca idealist ve hayalperest olarak görülmesidir. Bir medeniyetin kısaca 3 M'den oluştuğu söylenir: Mutfak, musiki ve mimari. Yaşadığımız coğrafyanın kültüründe bu üçünün de bir zamanlar müştereklere hizmet eden bir anlayışa sahip olduğu görülmektedir. Coğrafyamızda en güzel yemekler topluluklar için pişer, müziğimiz hep birlikte seslendirilir, evlerin avluları, köylerin ve şehirlerin meydanları en canlı mekanları oluştururdu. Belki de Hukukun ekolojisi kitabındaki idealizmin ve hayalciliğin en heyecan uyandırıcı boyutu tekrar müştereklerimizin hayata geçmesine ilham kaynağı olacak olmasıdır.

Dr. Öğr. Üyesi Hakan Dulkadiroğlu Ankara Yıldırım Beyazıt Üniversitesi 